\title{
Science + Space + Society: urbanity and the risk of methodological communalism in social sciences of space*
}

\author{
J. Lévy ${ }^{1}$ \\ ${ }^{1}$ Chôros Laboratory, École polytechnique fédérale de Lausanne, Switzerland \\ *This text is the revised version of the Geographica Helvetica Lecture at the International \\ Geographical Conference in Cologne, 29 August 2012.
}

Correspondence to: J. Lévy (jacques.levy@epfl.ch)

Received: 5 August 2013 - Revised: 9 April 2014 - Accepted: 11 April 2014 - Published: 22 July 2014

\begin{abstract}
During the last decades, geography has lost its epistemological exceptionality, but is this enough? Social sciences are commonly threatened by methodological nationalism and, more generally, by methodological communalism, that is the corruption of a scientific approach or project by any kind of other social alignment that undermines its capacity to develop a free, autonomous thought. Has geography escaped these pitfalls?

In this text, the example of urban studies is taken to try and answer these questions. More specifically, the way the idea of spatial justice has emerged in the last decades is explored through the analysis of five significant books among the academic production on these topics. It is then argued, thanks to a critical review around the iconic notion of 'gentrification', that the corpus at stake is more substantial than the limited, partially arbitrary selection of these five books. The present-day situation of urban geography (and probably of urban sociology, too) shows a serious risk of methodological communalism particularly located in Anglophone, and especially North American, literature.

Some hypotheses are proposed to explain this particular geography of the academic episteme of inhabited space. It is argued that the potential single-paradigm hegemony in geography and, more generally, in social sciences might fuel this danger.

Finally, a possible antidote to this worrying trend could be the simple, but complex idea of putting science, space and society together in a non-dissociable way. The conclusion stresses the necessity of taking up key challenges that urbanity issues raise and the usefulness of epistemological and theoretical pluralism as a major intellectual resource.
\end{abstract}

\section{Introduction}

Geography has changed a lot since the 1960s. By and large, it can be argued that it has left its isolationist paradigm, established multiple contacts with other fields and overcome its long "self-landlocking" attitude. Geography has lost its epistemological exceptionality, but is this enough? Social sciences are commonly threatened by methodological nationalism and, more generally, by methodological communalism, that is the corruption of a scientific approach or project by any kind of other social alignment that undermines its ca- pacity to develop free, autonomous thought. Has geography escaped these pitfalls?

In this text, I will take the example of urban studies, and more specifically the way the idea of spatial justice has emerged in the last decades. I will start with an analysis of five significant books among the publications on these topics. Then I will show, namely by developing a critical review of the iconic notion of "gentrification", that the corpus at stake is more substantial than the limited, partially arbitrary selection I made of these five books. The present-day situation of urban geography (and probably of 
urban sociology too) shows a serious risk of methodological communalism, particularly located in Anglophone literature, especially North American. I will offer some hypotheses to explain the particular geographical differentiation of the academic episteme about inhabited space. I argue that the potential single-paradigm hegemony in geography, and more generally in social sciences, might fuel this danger.

Finally, I propose an antidote to this worrying trend: putting science, space and society together, in a nondissociable way. I will conclude on the necessity of taking up key challenges that urbanity issues raise, and on the usefulness of epistemological and theoretical pluralism as a major intellectual resource.

There are therefore different truth regimes in this article: empirical-analytic (Sect. 2), empirical-synthetic (Sect. 3.3), theoretical-demonstrative (Sects. 3.1, 3.2), and theoreticalconjectural (Sect. 3.4). The reader is invited to accept the relative heterogeneity of the argumentative style. I hope they will, at the end of the day, be convinced by the consistency and relevance of the overall approach.

\section{Spatial justice in the city: five books}

The issue of spatial justice is a fascinating topic. It is present in a significant number of urban geography-tagged publications, especially in North America. As early as the 1970s, stimulating essays on this topic were released. Personally, I have to admit that my first reflections on this topic were published no sooner than the early 1990s (Lévy, 1994) and that I am still working on a more comprehensive theoretical approach (Lévy, 2013).

The adjunction of the adjective "spatial" to a supposedly non-spatial justice raises number of epistemological and theoretical problems that geographers are just beginning to tackle. The risk here is to simplify the answer to one or more of these questions: who defines what is just, and how? To what extent could space be something other than a neutral container of un/just items? Could geographers' work bring a specific contribution to the public debate on justice?

In the light of four books, I will examine how it is possible to identify a "North American" way to spatial justice. A fifth one will give a sort of counterpoint, a beacon to help us locate, in space and time, this small corpus. These books are

David Harvey (born 1935), Social Justice and the City (1973, new edition 2009);

Neil Smith (1954-2012) and Peter Williams, eds., Gentrification of the City (1986);

Neil Smith, The New Urban Frontier: Gentrification and the Revanchist City (1996);

Edward W. Soja (born 1940), Seeking Spatial Justice (2010); and the fifth

Susan S. Fainstein (born 1938?), The Just City (2010).
It can of course be argued that I could have added more books to the list or even chosen different books. In the light of recent discussions about spatial justice in the city it can be argued that, in spite of the rapid evolution in this domain, these already classic five books represent an acceptable, compact as well as substantial summary for the current state of progress in this field.

\subsection{Social Justice and the City $(1973,2009)$}

Social Justice and the City was published in 1973. In 2009, David Harvey released a new unchanged edition, with the addition of an article that had been published in The New Left Review in 2008. In this first "Marxist turn" opus, Harvey emphasises the idea that "social justice" can be considered an alternative to a merely spatial approach.

In chapter 2 (pp. 50-95), Harvey gives an image of a frozen urban space, where rationales of land price force activities and residential functions to be located in strictly divided-up, permanently specialised areas. The explanation is that the poor are forced to stay in high-price districts because the rich occupy the periphery and because zoning logics hinder useful spatial rearrangements (chapter 4). He blames this situation for creating absurd spillovers and explains this gridlock thanks to a socio-political analysis of different groups' strategies. For Harvey, however, beyond the "groups" it contains, the city itself (or some larger societal space) does not exist. He examines conflicts inside urban society as if there was no urban society. The political scene is viewed as a geopolitical battlefield where groups are irremediably solid and act like states (pp. 73-9), all the more since they are unified by unchangeable "social values": the poor, for instance, are reluctant to intra-urban mobility because it has a higher cost for them (79-86). The title of chapter 4 evokes ghettos and the necessity to get rid of them, but no solution is proposed.

Later in the book, Harvey refuses to endorse Robert Park's statement about cities as "workshops of civilisation" and his invitation to build a theory of the city as a "social entity". What a paradox! Harvey spends the first half of his book sketching a theory of the city but finally refuses the very idea of constructing it. He only accepts a strongly economicist approach, along with strong currents among North American social scientists (see, among many, Sassen, 1991). This approach sharply contrasts with that of Jacobs (1969), who explored cities as economic organisations. Her contribution seems to be ignored 20 years later, as if economicist approaches agreed to neglect, and even ignore disrupting propositions. Here, although Marxism and neo-liberal approaches diverge on the interpretation of economic on many points, they clearly converge to deny any autonomous explanatory power to spatial configurations.

Moreover, among economics-driven social theories, Harvey has chosen a particular approach (Ricardo-Marx's theory of rent) which comprehends the price of urban space as a 
rent, that is a non-produced monetary advantage, depending on outer logics, such as geology in the case of oil or pedology in farming. It could be argued, however, that the financial value of an urban piece of land is precisely the result of all the non-financial aspects of urbanity. Here Harvey neglects his own 1969 criticisms of the "absolute space" framework as he explicitly admits that the idea of an absolute space is relevant in this case: in some parts of the city, he says, the land price is high because it is alone in its category and it would not be possible to produce a similar, competitive product. These privileged places play the same role as a favourable physical milieu in classic geography.

Hence his use of the "monopoly rent" concept, although it is particularly difficult to apply to North American cities, which have proven their huge capacity to change the geography of their land prices, namely through the massive spatial dynamics of the 1940-1970s (the "urban flight") and seem therefore to be a specially bad client for this notion. Even in European cities, where the enduring strength of perceived heritage and the existence of more substantial "urbanophile" social groups have prevented a similar "flight" in the historic centres, we can observe a large variation in the attractiveness, and, as a result, of the land price between the 1950s and today.

In fact, what Harvey does is propose an urban theory that deliberately ignores what makes a city a city, that is the repetitively reproduced spatial comparative advantage coming from the combination of density and diversity. He inscribes the city's issues in a zero-sum social game and creates the intellectual base to promote a conservative stance in politics, since in this context any change would mean, according to him, more freedom for the exploiters and more exploitation for the exploited. Hence a new paradox: Harvey does not challenge the monopolistic trends of capitalism, unlike many Marxism-inspired political discourses, but at odds suggests, in a purely defensive way, to comfort the functionalist fragmentations produced by this trend during the Fordist period. In other words, the classic Marxist idea that the contradictions of the capitalist system should be used as a leverage to overcome them and construct a new, superior society is totally absent. From the Marxist corpus, Harvey erases the progressive component. This dimension is derived from the Enlightenments and had been re-read by Marx, after Hegel, and has been revamped as a historicist messianic, missionary narrative. With Harvey, the Marxist inheritance is reduced to a portrait of the present as a purely negative, hopeless situation and the only just attitude is to resist any change.

As a result, for Harvey, "the concept of social justice is not an all-inclusive one in which we encapsulate our vision of the good society. Justice is essentially to be thought of as a principle (or a set of principles) for resolving conflicting claims." (p. 97). In this perspective, Harvey sees justice as a mere set of redistributive tools. He tries to adapt the discussions devoted to individuals, like in the works of Rawls (1971), to territories. He does so without precaution about a possible the- oretical gap between the two rationales. He solves the problem by the mediation of "needs", which represent for him the first requirement that each territory should meet (p. 116). The concept of society is absent in the premises as well as in the geographical implications of "regionalization", where a technocratic approach ("interregional multipliers") seems to prevail in his thought.

Taking examples, Harvey praises urban policies in Cuba (138) and the country/town split policy during the Cultural Revolution in China (237). However, beyond the cruelty of the various feedbacks recent history has sent him, what is important here (see chapter 6) is the arguments Harvey provides: he denies a productive efficiency to cities because for him the spatial concentration that characterises cities is just one aspect of the surplus-value concentration that is in the hands of capital-holders. He equally admits that a socialist policy should encompass measures to curb the urbanisation process. He gives a chance to "generative" cities in opposition to "parasitic" cities, and we understand that a city is "parasitic" when its inhabitants consume all the surplusvalue produced, or even more, because of the absence of due redistribution to the countryside. This is a very outdated, materialicist view of production. We also find a typical Engels-inspired (The Urban Question, 1872) thought, where the rural/urban divide is seen as a product of capitalism and where the generalisation of urbanisation (which is actually happening) would be a totally inacceptable prospect because urbanity ("urbanism" in Harvey's terminology) is definitely refused as a "productive force" and mostly defined as a side-effect of the capitalist-production relationships. Here, in spite of later recurrent tributes to Lefebvre, it can be argued that Harvey has taken leave of Henri Lefebvre's urban revolution (302-314) as soon as 1973.

As a matter of fact, in his 2008 additional text, Harvey does not show an evolution in this regard. He uses the expression "neo-liberalism" many times and does not only understand it as an ideology but also as an actor, actually the only significant actor of the present-day. Nor does he suggest the least attenuation in his glorification of the Chinese Cultural Revolution, in spite of the undisputable evidence of the unchained despotic violence that constituted its core. This confirms both the flawless structuralism of his paradigm and the bold involvement in a stance where it is impossible to distinguish research statements from political activism.

In short, in 1973 Harvey proposes a Marxist turn that leads to adopting a reductionist economic approach that takes us a step backward in the understanding of space, and that generates great confusion between science and ideology.

In the supposedly completely blocked situation Harvey evokes, we can understand how surprising, for Harvey and his disciples, the unthinkable event that has occurred since the 1980s in North America would have been: the city and its inhabitants put themselves on the move unexpectedly, and this was the result neither of a governmental decree, nor of the kind of political movement Harvey had promoted. For 
instance, in his book, Harvey presents the end of the ghettos and the emergence of an effective demand for public transportation as totally impossible.

What actually happens when theory is so obviously challenged by empirical processes? For some, it means a calling into question of the theory. Others opt for a headlong rush that makes the divorce between theoretical statements and empirical feedbacks less easily manageable. This second option has been that of the emerging mainstream of American geography. And this is where Smith steps in.

In his book (p. 282), Harvey had already given the line: playing communal identities to resist the penetration of the market, that is to say pre-capitalist communal geopolitics against capitalism. Neil Smith's works take place in this perspective.

\subsection{Gentrification and the City (1986), The New Urban Frontier: Gentrification and the Revanchist City (1996)}

As early as 1986, Neil Smith had given a concrete meaning to this orientation by the characterisation of the current urban trends as a "gentrification" movement. We have to acknowledge his pioneering role in this field. The first book, Gentrification and the City, was actually a collection of papers edited by Peter Williams and himself. It has a more precise continuation with another of his books, published in 1996, The New Urban Frontier: Gentrification and the Revanchist City. Some topics, such as the "frontier" or the "rent gap", were already present in Smith's contributions in 1986, but in 1996 he offers a more consistent set of arguments, especially with the introduction of two examples (Harlem and the Lower East Side of New York City) and the assertion of a new concept, the "revanchist city", that says the poor are expelled from their neighbourhood by the intentional action of capitalists. Let's take a look at the current evolution of these places.

In Harlem, the "White" population reached $9.8 \%$ from $2 \%$ in 2000 . The overall movement in New York City reveals a decrease in homogeneous areas, the "White" ones as well as the "Black". The "Asian" and the "Hispanic" areas are more contrasted, with an increase of concentration in some Queens and Brooklyn areas. The ghetto logic is slowly counterbalanced by logics of diversity. Is this "revanchist city"? According to Smith, the revanchist city "expresses a race/class/gender terror felt by middle- and rulingclass whites [...] It portends a vicious reaction against minorities, the working class, homeless people, the unemployed, women, gays and lesbians, immigrants." (211).

Table 1 shows a comparison between a territory encompassing the Lower East Side and East Village and New York City as a whole.

As we can see, the traditionally strong presence of the Hispanic population and relatively low percentage of Black people in this area are still visible, as people of Asian origin are

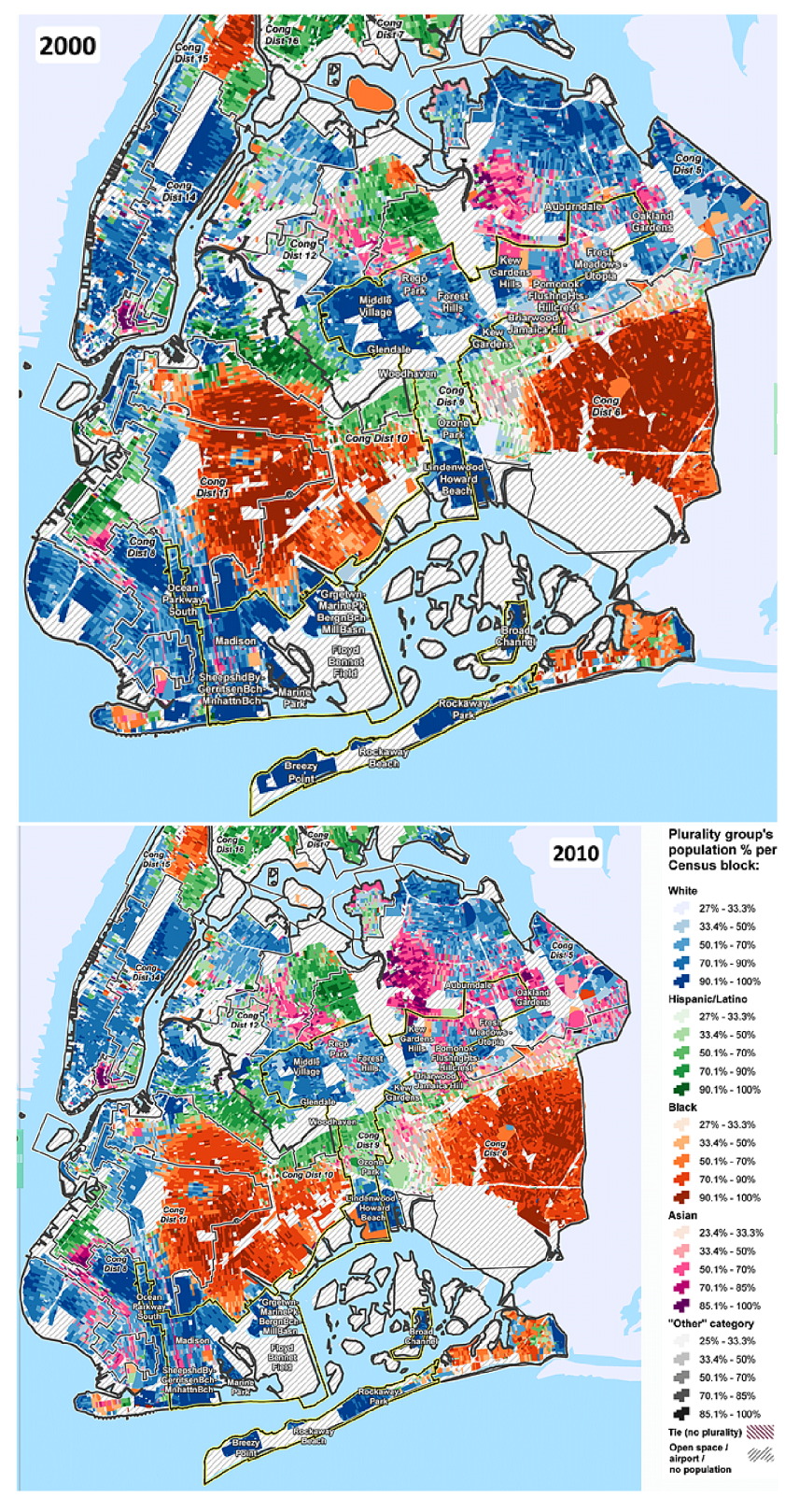

Source: Cuny Mapping Service, Center for Urban Research, The City University of New York (CUNY),
<http://www.urbanresearchmaps.orgz

Figure 1. Ethnic enclaves in NYC, Upper Manhattan, Lower Manhattan, 2000-2010.

overrepresented in the geographic wake near Chinatown. In spite of this confirmed peculiarity, the overall share of "minorities" in the district (61.3) is perfectly comparable to what it is at the New York City scale (66.7).

Information about income strengthens this interpretation. What happened was not a "hidden" economic gentrification that would have been masked by the permanence of nonEuropean groups. In this hypothesis, the richer part of the "minority" groups would have taken the place of the poorer one. To the contrary, this area remains a neighbourhood 
Table 1. East Lower Manhattan: a concentration of New York ethnic diversity.

\begin{tabular}{lrr}
\hline & Lower East Side + East Village & New York City \\
\hline Total population & 117093 & 8175133 \\
White non-Hispanic & 38.7 & 33.3 \\
Hispanic origin & 29.3 & 28.6 \\
Black/African American non-Hispanic & 8.3 & 22.8 \\
Asian non-Hispanic & 21.1 & 12.6 \\
Others & 2.6 & 2.8 \\
Median household income (US \$) & 39780 & 50285 \\
\hline
\end{tabular}

Source: 2010 Census Data, New York City Department of City Planning,

http://www.nyc.gov/html/dcp/html/census/popacs.shtml.

where deprived people are overrepresented in comparison with the rest of New York City, which is confirmed by the statistics that detail income brackets (see New York City Department of City Planning census data). The diachronic meaning of this situation is confirmed by the 2000-2010 comparative maps: the arrival of middle-income people has significantly, but not totally, brought this area closer to the city's average.

If you go to the heart of the East Village, Tompkins Square, which was at stake, according to Smith, in the eventually lost battle against "gentrification" and which lies in the richest precinct within the Lower East Side-East Village districts, you will find Smith's idea of "revenge" hard to recognise. These are some photographic examples of the atmosphere of this area, taken during the summer of 2012 (Fig. 2).

On these pictures, we can see refurbished buildings, active public spaces, and clear sociological diversity, including both people with high cultural assets and the very poor. In short, this supposed "revanchist city" is nothing but a high concentration of New York's diversity as a whole. The population movement of the last three decades has transformed a Hispanic ghetto into a neighbourhood whose mix sums up, in a local style, that of the overall urban area. We could do the same about Harlem.

If I have included this short empirical - statistical and visual - observation, it is just to make more visible the fact that at a certain level of theoretical self-confinement, it becomes impossible to manage the inevitable, useful disturbance that the outer world generates on our theoretical propositions. In Smith's case, the first arrival of one non-poor Black inhabitant in Harlem was evidence of the rich Whites' overwhelming "revenge". At this stage, self-criticism becomes highly unlikely. We can observe instead the creation of new ad hoc theories detecting even more vicious conspiracies than the one announced before.

Beyond this point however, what is striking here is that Smith focuses only on Manhattan examples, that is to say the city centre of the NYC metropolitan area, a place where, as in a huge majority of the cities throughout the world, these "minorities" are more significant and mixed with the rest of the population than everywhere else. During the last four decades of urban renewal in Europe and North America, city centres have either confirmed or reinforced their specificity of being the most dense and diverse districts, which is absolutely not the case in North American suburbia or in European peri-urban areas, and this fact seems to leave Smith indifferent. Why concentrate the criticism, and not a mild one, on places where a social mix works - although with effective fragilities and weaknesses - and is supported both by the inhabitants and by the local governments? Furthermore, those areas are in the majority, and much more than in previous periods, managed by the Left in the United States as in Europe. In 2008 and 2012, Harlem and the Lower East Side voted 85$90 \%$ in favour of Barack Obama. Twenty years after Smith's claim that the "revenge" had begun, these neighbourhoods have rather confirmed their strong social-mix identity.

Summing up Smith's approach, we can identify (i) a lack of a consistent social theory; (ii) the reduction of space and spatialities to a mere list of locations, and (iii) a clear activism-oriented discourse.

The emerging point is that political oppositions are described with a civil war vocabulary. In comparison with Harvey, Smith's "battlefields" fierceness has gained ground, and violence has become a founding value for politics. The militant tone is even more radical than in 1973 with Harvey.

\subsection{Seeking Spatial Justice (2010)}

Seeking Spatial Justice is probably the first book that identifies spatial justice as a major issue, which justifies devoting a complete book to its exploration. Herein lies the remarkable aspect of this work. However, Ed Soja remains in the tradition of geography, as he considers it to be a relatively secluded field: he very rapidly mentions the debate on justice that occurs in other intellectual disciplines or topics. Moreover, in the wake of previous work, his book includes a vibrant tribute to Harvey's Social Justice (48f. and $81 \mathrm{f}$.) and to Harvey's overall approach. He namely supports the idea that the 2008 crisis is a "crisis of urbanisation". Here Harvey has surprisingly reduced the city in general to the real estate financial sector. 

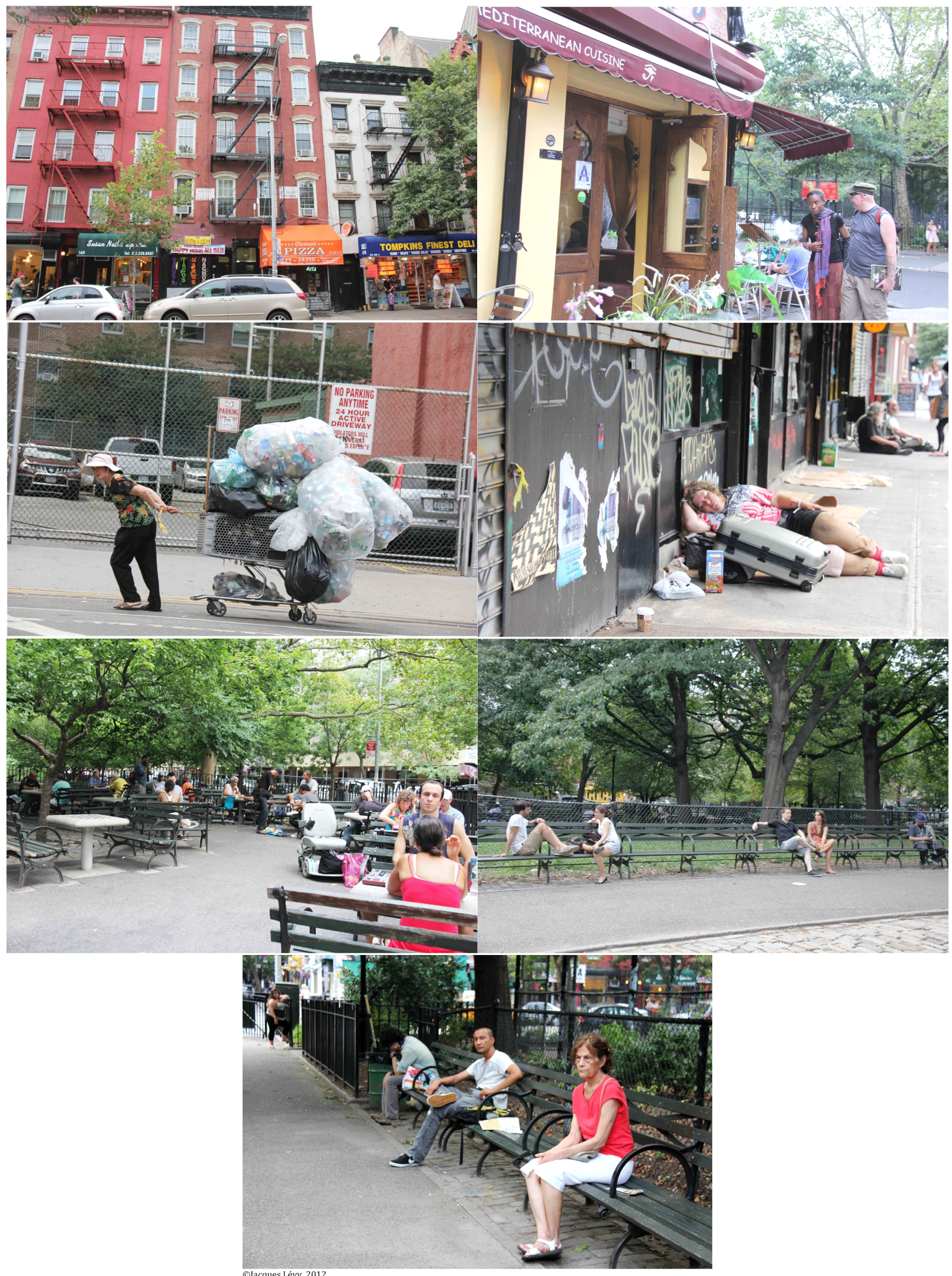

Figure 2. Tompkins Square Park, Summer 2012. 
The example that starts the book and underpins all Soja's thought takes place in 1996. At that time, the Bus Riders Union (BRU) had obtained a court decision that forced the LA transportation authority (MTA) to transfer investments from the underground to buses. Another example is Mt. Laurel, NJ (in Philadelphia's urban area), where a conflict had burst about the possibility of limiting the social housing part in a district where the low-income population share was overwhelming. This case is comparable to the happy-ghetto approach developed by Smith. In the BRU vs. LA County case, however, communalism takes a more original shape: what was at stake here was the co-spatiality (Lévy and Lussault, 2013) between two layers of the urban public transportation network. Everywhere in the world except in Los Angeles, there is a consensus among users, scholars, and decisionmakers to think together and to connect as well as possible all the spatial layers of public mobility (including pedestrian metrics) and to assert public mobility over private mobility. Another consensus exists on the necessity of long-term investments to make efficient a multimodal public transport network.

In the Los Angeles of the late 1990s, the modest, slowly growing subway and light rail scheme was explicitly presented a first step in a multi-decade plan. (In 2013, there are two subways, four LRT, and two BRT lines.) It could then have been consistent that all the forces that favour public transport converge to put claim to more public investment in transport in the overall LA urban area, to the detriment of freeways. In the Los Angeles urban area, about $90 \%$ of the land surface is devoted to cars through roads or parking lots, which is a world record among the metropolises of this size, and it can be argued that this general privatisation of space contributes to the rise of serious problems for the local society. Of course, it is not Soja's fault if a pro-public mobility political coalition had not emerged at that time. However, he uses a strange definition of justice when he sees a positive evolution towards spatial justice in the fact that, in LA, different layers of this public mobile space oppose each other instead of cooperating and that the poor (the bus riders) have won against the slightly less poor (the subway riders). The communal approach to urban processes shows here its "creativity".

Actually, for Soja, segregation is not a bad thing as such, on the condition that it is a self-segregation. In a short side development (pp. $55 \mathrm{f}$.), he opposes the unjust (since imposed) "ghetto" to the just, since self-created, and socially homogeneous district he calls an "enclave". This important statement appears incidentally in the middle of a chapter, as if this kind of assertion did not require an in-depth demonstration. Thus, for him, a just space is a space where the fragmentation of urban logics should be preserved.

In chapter 2, Soja analyses different unjust situations: higgledy-piggledy Parisian suburbs, the Israel/Palestine disputed territory, the South African apartheid, or urban conflicts in the US. This odd list is made possible by the lack of a concept of society that would have allowed to differentiate between intra-societal or inter-societal realities.

Soja affirms in this book, as in others, the importance of space. But what space? For him, separation is the only relevant issue. The "right to the city" is the right to preserve the homogeneity of communal areas. In spite of Soja's frequent invocations to a Lefebvrian patronage, the legacy is all but obvious. Soja tries to reconcile Harvey and Lefebvre and to smooth his own differences with Lefebvre's concepts (pp. 92-105). These differences are actually substantial, since Lefebvre's notion of "centrality" (close to what we now call urbanity) is the exact opposite of Soja's justification of self-segregation.

Finally, Soja does not take into account politics as production of legitimacy. He only seems interested in exploring tactical bypasses that judicial power or street struggles may offer in the scope of non-cooperative approaches to social life. This is compatible with a "geopolitical" view of intrasocietal conflicts. Notions like public space and urbanity, which would require a concept of society to underpin them, are ignored.

In short, we can find in Soja's book an assertion of the epistemological centrality of space, but with little theoretical impact, and high praise for self-segregation, as part of an advocacy-oriented discourse, which, as a result, remains feebly open to alternative reasoning.

We can make a stop here and summarise what is largely common in Harvey's, Smith's and Soja's approaches. Spatial justice is defined by the supposed resistance carried out by the exploited, the level of justice being measured by the efficiency of this resistance in an instable balance of power. However, justice is a social construct that to exist requires a public debate on pre-existing goals (a substantialist approach) or shared methods and values (a procedural approach). Any problem of justice, even if it is "situated" in a particular place or sector, implies an encompassing environment in which this debate can be set up, and this kind of environment can be named society.

Now, what is the attitude promoted by our three authors? They support the objective of maintaining by all means the status quo, even if it is characterised by a ghetto-style spatial fragmentation. How could such an agenda pave the way to a possible common horizon for all citizens?

Reading these works, we can imagine two interpretations. Either this view is part of a programme that aims at dividing space between social groups, and this logically leads to the management of the city as if it were made of distinct societies that entertain each other with zero-sum geopoliticallike relations; or it is a solely conservative stance, which consists in defending at any cost the pre-existing situation. Or it is both. In the first option, we find a clear rejection of an open interchange amongst citizens in the various aspects of a public sphere (Kant, Arendt, and Habermas' Öffentlichkeit) that is embodied by the explicit political scene. This rejection also affects ordinary life's civility processes in 


\section{Go Metro}

metro.net

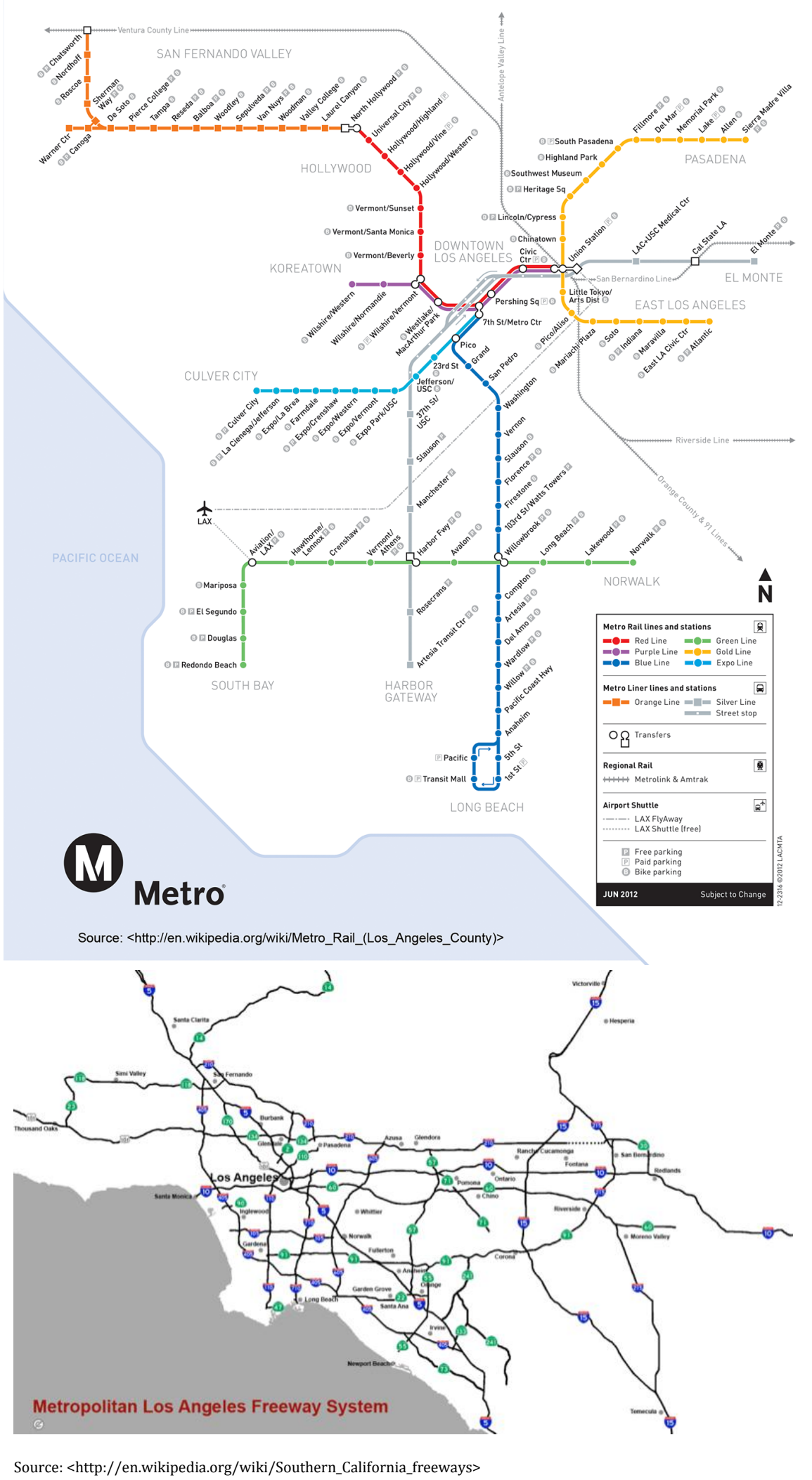

Figure 3. What is at stake in LA Transport System? 


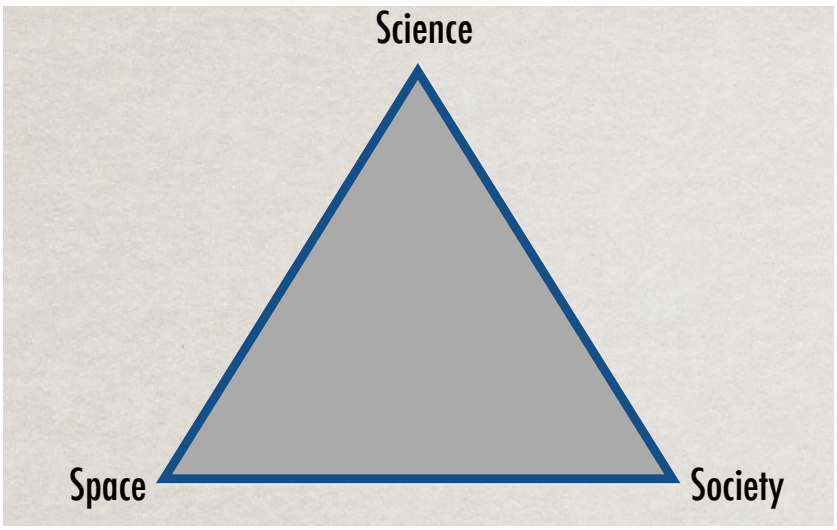

Figure 4. The 3 Ss triangle.

the urban public space (öffentlicher Raum). In the second option, the no-change posture makes it impossible to envision the self-perfectibility of society, which has been the starting point of the Enlightenment's overall paradigm and represents the ethical base of today's democratic republics. In both cases, the search (including through democratic political struggles) for the legitimisation of certain values (such as a certain idea of justice) by society as a whole becomes impossible. With Harvey, Smith, and Soja the deprived only have the option of raising walls around them, both literally and figuratively, and interiorising inevitable defeats.

\subsection{The Just City (2010)}

Although published the same year as Soja, Susan Fainstein's The Just City is significantly different from the others books analysed here, first of all because it includes spatial justice in the "grand" debate on justice carried out by social sciences and political philosophy.

In contrast with the four other books, we do not find in Fainstein's work the militant stance that frequently jammed theoretical argumentations. This does not mean however that Fainstein does not try to bridge theory with urban agency. Quite the contrary: she is a professor of urban planning and adopts a much more pragmatic posture, in both senses of the word: action-oriented and non-dogmatic. This is of no surprise. We have noticed in Europe and even more in North America that the capacity of encompassing major elements, such as the criticism of the "Modern Movement" in urban planning, the multiplicity of urban actors in terms of coproduction (and not only as a "resistance") and the pivotal importance of public space in analysing urbanity, is much more present among reflexive practitioners than pure scholars in geography or urban sociology. In the US and Canada, the "Urban Renaissance" process has been taken seriously by urbanists, while it has often been neglected or mocked by sociologists or geographers.
However, Fainstein also proposes a much more inclusive review of the existing literature and a more critical, personal comment of mainstream ideas. She openly criticises the neoculturalist (she calls it "post-culturalist") approaches that try to confine and block individuals into non-chosen groups. She supports the concept of equity, compatible with a society where public authorities and individual actors co-produce urban realities. In brief, she marks a break with the vintage Marxian structuralist style of the first three authors discussed here. Concretely, Sen and Nussbaum's concept of capabilities is used as an alternative to the technocratic, naturalist notion of "needs" Harvey likes to use. In this approach, Rawls' primary goods are to be evaluated not only in terms of their direct equalising redistribution effects, but of their capacity to empower actors too.

What leaves the reader partially unsatisfied in Fainstein's book though is the counterpart of her pragmatism: the lack of a theory of the city and urbanity. Actually, there is society here, but little space. As a result, she does not explain clearly why her three guidelines for urban agency (democracy, equity and diversity) are chosen, rather than alternative principles. Thus, she does not acknowledge the logical link between diversity and density: she addresses density as a neutral, technical issue that should not be put at the same level as diversity. We could however object that if you pull out density, diversity can easily diverge from the basic definition of a city: the world as a whole contains a maximum of diversity but it is only when it is coupled with density that the idea of city can emerge.

Strangely in an urban planning essay, she does not pay much attention to public space, in spite of convincing works that show its founding relation with urbanity (see e.g. Lofland, 1973, 1998). She does not develop a serious discussion about terms that remain ambiguous in her text either, such as "individualism" or "community". Moreover, she does not link the urban agency to the concept of development, as if a city was the container of social problems but not a productive arrangement.

Finally, Fainstein offers a convincing synthesis of procedural urbanism, which gives a relatively limited role to public players, who are understood as referees more than stakeholders. The absence of the concept of actors results in a goodsounding general phronesis, but it lacks in strategic thought. Fainstein's framework is, in short, characterised by a clear criticism of neo-structuralist statements, by a careful, pragmatic approach of urban agency, and a relatively elusive theory of urban space.

\section{Academic configurations and epistemic risk}

In the first part of this text, I proposed a critical review of five selected books that address the issue of spatial justice in urban environments. In the following section, I will try to somehow generalise my statements by taking into account 
a more extended corpus of academic productions in urban geography. The first step will be to observe the fact that social sciences are not immune to what I call methodological communalism, that is the corruption of scientific propositions by any kind of ideology resulting from the alignment to a determined community. A possible antidote to this attitude could be based on a clear association between epistemological ("science") and theoretical ("space"/"society") requirements.

\subsection{The pervasive danger of methodological communalism in social sciences}

For geography, being part of a common market of methods or propositions with the rest of social sciences does not guarantee, in itself, the quality of approaches and frameworks. Thus social sciences are commonly threatened by methodological nationalism (Wallerstein, 1991; Wimmer and Glick Schiller, 2002). This weakness is a component of a more general risk, which could be called methodological communalism.

By this expression I mean the corruption of a scientific approach or programme by any kind of other social alignment that undermines its capacity to develop an autonomous thought. In this scope, communalism is a form of social incorporation in which an individual delegates their power to a group. Nation and nationalism are one of them, but class, gender, or ethnic groups can equally be mentioned. In the realm of scientific research, methodological communalism means that the allegiance to a group will be stronger than the orientation towards an open cognitive construction, as unprejudiced as possible. This will predetermine conceptual statements and preclude theoretical work from any substantial disruption coming from tensions with empirical realities. In a paroxysmal performance, this attitude can lead to denying to a non-member of the group the study of fields the group reserves for itself: "Black studies" or "Feminist studies" are, at least in their principle, good examples of this posture. Should we be an African-American person to study African-Americans or, even more serious, to be a feminist woman to study women? In its very construction, the expression "Feminist studies" creates an ambiguity between the topics (women, sex discriminations, gender issues, sexuality, sexuation, etc.) and the producer of the discourses on these topics.

Corporatism can then be seen as a "weak" variant of communalism, that is to say an allegiance to an organisation or an institution that, in return, provides some legitimacy. Methodological corporatism operates when a scholar voluntarily accepts a loyalty to an establishment that impacts the way he or she thinks. This can encompass ideological and political commitments, or the belonging to social aggregates such as academic disciplines, fields or topics, including the academic world as a whole, whose raisons d'être include, directly or not, statements about the contents of scientific research. In this corporatist variant of communalism, reversibility is in principle possible, but practically not so easy to carry out because of long-time inertia of career rationales and personal commitments. As a result, what has been said about communal allegiance can often be extended to this case.

Because we are in academic contexts, methodological communalism also supposes intellectual foundations that legitimate these interferences. Historically, "post-modernism" and "post-structuralism" have played the role of a powerful intellectual support to methodological communalism. Postmodernism is a complicated set of ideas, which cannot easily be summarised, but one of its components has been the tendency to undermine the idea that scientific propositions have specific rules of construction and enunciation, in comparison with other discourses. Here we must distinguish postmodernism from constructivism. Against positivism, the latter shows how science is neither a revelation nor a disclosure of pre-existing essences, but a social practice that constructs a certain type of discourse following certain rules and objectives within a certain culture. The former, however, claims that there is no significant uniqueness in scientific construction, that science only has conventional or institutional particularities in comparison with other discourses. This makes a delegitimising of science as a particular, socially useful cognitive realm possible.

As for the expression "post-structuralism", it is strange since it designates rather a neo-structuralist approach. Here we can be misguided by the gap between words and their apparent meaning. Lazega (2011) "neo-structuralism" could actually be qualified as post-structuralist as it gives actors, and namely individual actors, a paramount role in the dynamic of social networks. Conversely, the mainly North American aggregate of self-titled "post-structuralist" works can be defined as neo-structuralist. First, because it continues the structuralist tradition of explaining social worlds without human agency but with the help of overhanging, fixed and blocked "structures". In early structuralism (in the mid20th century), reductionist models could be class struggle (Marxism), language formalism (structural linguistics), kinship ties (structural anthropology), or the Unconscious (psychoanalysis). In "post"-structuralism as in classic structuralism, the concept of actors is still refused to individuals and it is awarded to collectives only if these are representatives of unchosen groups such as class, race, or gender. Second, this approach refurbishes the assumption that the researcher's location in the "space" of social positions determines their discourses ("positionality", "situatedness") a stance many Marxists long ago used to undermine any refutation of theirs theses. In this case, we find ourselves in a paradoxical situation in which communalism is not only an excuse but becomes a claim and a fresh base for a highly disputable scientific legitimation. The similarity with the Stalinist approach to knowledge ("bourgeois" vs. "proletarian science") is striking: your ideas are not receivable because you are speaking from the wrong side. This issue is extremely serious because what is at stake here is whether social scientists are entitled 


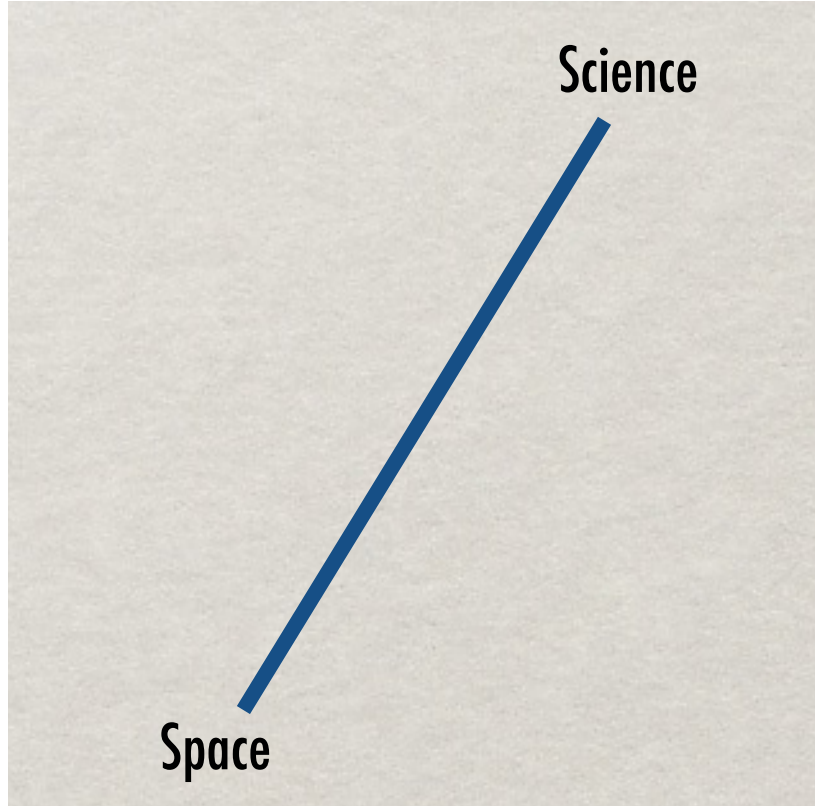

Figure 5. Lack of society.

to discuss other scientists' propositions on the sole base of their consistency and their relevance.

\subsection{The $3 \mathrm{Ss}$ as the pivotal triangle of epistemological stances in geography}

Has geography escaped this pitfall then? To try and answer this question, we can specify the particular rationale of geography among scientific domains. As a social science of space, geography has to manage three concepts beginning with an s: society, space, and science.

At times when society has been forgotten, social scientists have created a variety of theoretical monsters. Some geographers have in particular invented the myth of "general laws of space" whose effective outcome turned out to be of very limited interest. In geography as in other fields, the oblivion of society has also led to methodological individualism, essentialist culturalism, and naturalism.

When space has been neglected as a thick, thinkable dimension of the social world, geographers become sociologists or economists and, often, poor sociologists or economists. A geography without space is doomed to be a geography without science. A-spatial social theory, onedimensional social approaches which ignore the explanatory dimension of space, have dominated the cultural landscape of social sciences. This is clearly true for economics, but also for sociology or political science.

And, of course, when geographers have ignored the specificity, or the singularity of scientific languages, methods, and propositions, which are diverse but always rigorous and strictly defined, they have broken the knowledge contract

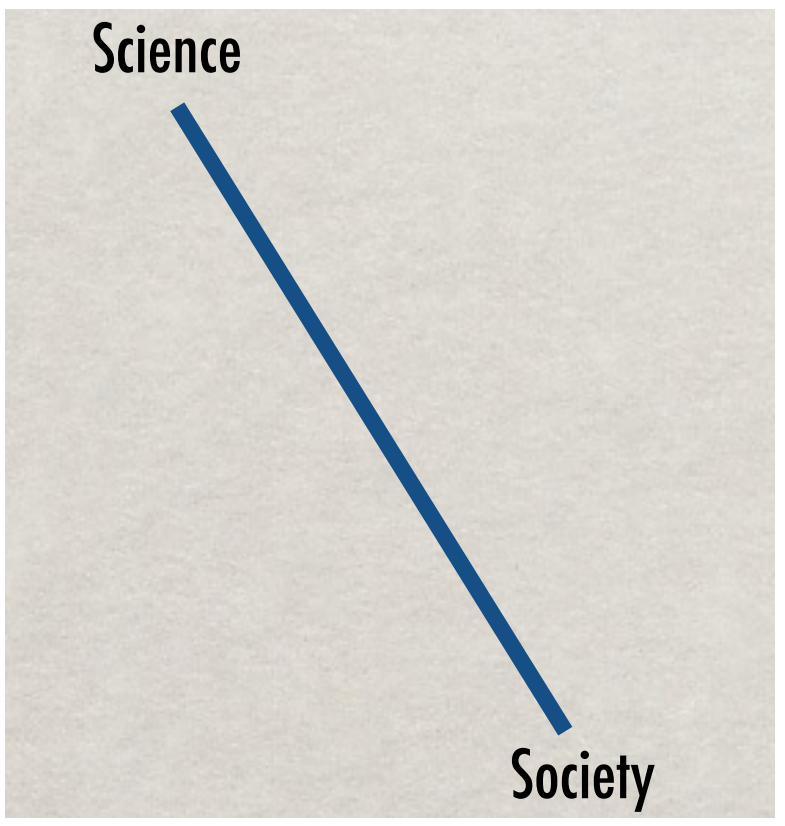

Figure 6. Lack of space.

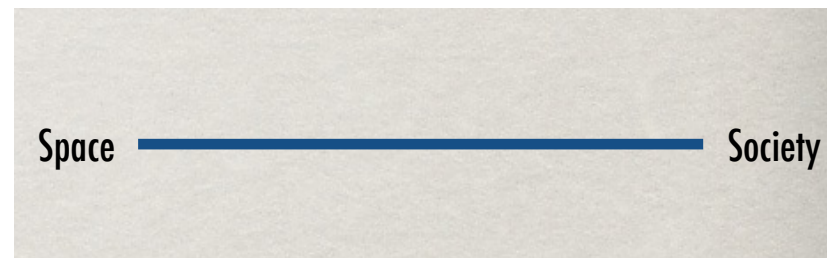

Figure 7. Lack of science.

that they concluded with the rest of society and with themselves. When they give up their scientific commitment, scholars speak like columnists, or activists. In geography, this attitude has made research drift towards spatial ideologies, spatial aesthetics, or geographical subjectivity, for example, not as new objects of knowledge, but as alternative stances to scientific work.

This leads me to make a dual hypothesis:

1. If we neglect any summit of the triangle, we lose an important component of our research device.

2. If we neglect any summit of the triangle, we weaken the overall epistemological construction of the social sciences of space.

This proposition makes it impossible to say: "OK, my geography includes little society, or little space, or little science, but it is good geography nevertheless." We cannot do good geography with such an approach. 


\subsection{Urbanity, "gentrification", and the conditions of an open scientific debate}

If the three Ss do not operate together, we can seriously doubt the cognitive use of geography. If we do accept this inseparable triad, we will have to address issues and questions that could not even emerge if one of the summits of our triangle was missing. We should then take space seriously, assume the statement that society is the general, effective actualisation of social worlds, and strive to reach, by a permanent reflexive effort, a dealignment of scientific research from other "pre-packaged" discourses: what does it mean for urban questions? The short list of the following issues is a possible translation of this general perspective in the more specific language of urban studies.

1. The nature of urbanity: is it a productive device (or a sub-product of a fundamentally a-spatial capitalism)?

2. Public space: is it a weak but profoundly political social tie (or a dangerous illusion)?

3. Can we talk of justice, capabilities, and public goods when talking about space (or is justice a mere redistribution of private goods)?

4. Does spatial justice take place in a society of spatial actors (or in a no-society, no-actors social environment)?

The example of "gentrification" shows that this "programme" is far from being accepted, not only by the promoters of the notion but also by its critics. The "gentrification" issue has produced a large amount of critical responses namely against the economicist and structuralist approach Harvey, and above all Smith, have developed. Scholars such as David Ley offered alternative analyses starting from 1978 (Ley, 1978, 1986), when geographers did not yet use the 1964-coined expression of "gentrification". Later, Hamnett (1991) presented an elegant synthesis of possible critiques to Smith's core rationale.

In spite of their fundamental opposition to the neostructuralist theses, these criticisms remain weak because they accept placing themselves on the very terrain of their antagonists. They do not challenge the dividing-up of the empirical reality that the term "gentrification" encompasses. The key issue is therefore vocabulary: gentrification is commonly used as a virtual synonym of the French embourgeoisement, since "bourgeoisying" does not exist in English and would probably have, if coined, another meaning. Why don't we name middle-class individuals that move to poor neighbourhoods "ghetto-killers" or "mix-makers" instead of "gentrifiers"? Although it has rapidly been used in a derogatory way, the term "bobo" (Brooks, 2000) is more accurate than "gentrifier", precisely because "bourgeois-boheme" people have the choice to dwell in different kinds of real estate-price locations. It is easy to prove that if this group did not exist, a geography solely made of land value-generated, homogeneous districts would spontaneously emerge. This is exactly what happened between the 1950s and 1980s in most North American cities, when the "urban flight" involved the huge majority of the middle class. We can see the difference with Europe here. In western European cities, people with high "cultural" capital remained in the city's historical centres, even when their incomes were low (they arbitrated in favour of smaller or less comfortable flats) and when the Zeitgeist was favourable to various kinds of de-densifying urbanisation processes.

The word "gentrification" embeds the idea that deprived persons or already segregated groups should be left in an inter se environment and that this would be a better situation than social mix. There might be objections that the criticisms I have formulated about spatial justice have been expressed much earlier than mine in the context of Anglophone and even North American scientific exchanges. This is true, but what I would like to point out is that neo-structuralism is too rooted in academic institutions to be significantly affected by these criticisms. Moreover, critical approaches generally accept the term itself as a scope for discussion without challenging it, becoming trapped in a type of discussion where it is impossible to say, and perhaps to think, that "gentrification" is not a good term for those trying to represent and formalise urban processes.

Thus, David Ley and Chris Hamnett's reasoning can be seen as a defensive move in a context where it is impossible to analyse what is actually at stake in the urban dynamics. In a more recently published reader (Lees et al., 2010), none of the authors challenge the relevance of the notion itself. The most recent contributions are part of the neo-structuralist stance, adding some gender, race, and "post-colonialism" to the classic Marxist structuralism. Gentrification has been naturalised and is not an object of discussion as such. Furthermore, one of the editors of this book, Slater (2006), like many other authors (such as Smith and Soja seen above), has clearly associated "social mix" to "neoliberalism", as a sort of confession that social mix is for him a situation that by no means should be accepted.

Much Anglophone literature in geography and urban sociology experience a cognitive dissonance which requires a 1984-like Newspeak discourse: it is not because "gentrification" is a danger for social mix (that which the construction of the word itself suggests) that it should be condemned but, on the contrary, because it enlarges districts' sociological spectrum and weakens ghettos. Would then "peace" mean war, and "truth", lie as well?

Eventually, it is not by chance that the rare explicit opponents to the supposed malignity of "gentrification" can be found only in the field of urban agency-oriented journals, which are more open to non-structuralist approaches to urban planning. A scholar such as Florida $(2002,2005)$, whose theories are in complete antinomy with the notion of gentrification, is forced to play on another field, with other rules and other kinds of legitimisation. He has virtually no protagonists 
to interact with on the academic stage, except those who try to de-legitimate the notion of "creative class" from two apparently opposing points of view. In the first case, they use a classic Marxist approach to blame Florida for refusing the communal notion of class and to label him as an agent of the "neoliberal" conspiracy (see for instance Peck, 2005). In the second one, Florida is guilty of promoting strong public policies and dangerous "big governments" (see for instance Malanga, 2004). In both cases, the reduction of urban rationales to pure economic mechanisms shows the difficulty, within academia, to take on the idea of a systemic, de-hierarchised approach to social logics and, simply, to understand what kind of social reality a city is.

If we connect the history of debates on urban topics to the history of urban realities, we are inevitably struck by their growing diverging course. On the one hand, after decades of urban flight and its consequences, a pervasive violence in the streets, the emergence of the "Urban Renaissance" does not appear as a pretentious motto, but as an effective bifurcation. It certainly makes sense that David Ley has explicitly used the Vancouver experience of urban regeneration as a primary case study to develop his critical statements on "gentrification". In this city, the urban re-encounter with urbanity began in the late 1970s, and the Expo 86 represents a first milestone in the process of urban regeneration.

On the other hand, the hegemony of neo-structuralism fuels a self-blindness about this phenomena. As a result, it is not easy to discuss the rough efficiency of social mix situations or policies with people that reject the very idea of social mix as the "revenge" of the bourgeoisie over the proletariat. All the intellectual construction of contemporary urbanism (I mean urban agency here, in the European sense) is underpinned by the idea that, through public space, sociological and functional diversity is at stake as an issue and a goal in every single action at any scale on the city. However, when you have in front of you scholars like Soja, as we have seen, or Mitchell (2003), who understand the right to public space as a synonym of a right to the ghetto, discussion is not easy.

These oppositions are part of a larger paradigm divergence and are not a problem in itself: pluralism in debates should be the correct response to the plurality of ideas. Now, is this the case in the academic scene of urban issues? Trouble begins when the hegemony of one approach practically discards all others. There is clearly a problem here in Anglophone literature: one single point of view is as overwhelming and omnipresent as the others have been (self-)censored.

\subsection{Hypotheses on geography and the Atlantic}

Is there a geographic dimension to these geographical debates? I would like to assume this perilous question and propose some hypotheses on this point. In North America, there are of course scholars that are not in line with the neo-structuralist paradigm. In Europe, there are naturally scholars that, conversely, clearly support it. What I would like to point out is the difference in the location of the gravity centre for each of these "epistemic continents". In North America, Marxist and culturalist versions of neostructuralism are dominant in geography and urban sociology and in a large part of anthropology. As in many other aspects of contemporary culture, Britain is not easily classifiable. In this article, I will not try to identify the specific role of British geography. To provisionally avoid this problem, I will restrict Europe to "continental", non-Anglophone Europe in the following reflections.

At this level of generalisation, the status of this text can only be one of conjectures. The cognitive aim of this last section is nonetheless dual: (i) to present these hypotheses so as to encourage discussion on these too-neglected aspects of "laboratory life" (Latour and Woolgar, 1979); and (ii) to show that universality (in practice, globality of science) is not an immediate operation, even less a magic one, but that it is constructed by transforming pre-existing epistemic configurations which are strongly differentiated geographically.

\subsubsection{H1 Science: the European experience of a slippery mix}

On the European side, the undesirable consequences of the slippery mix between science and ideology that the Marxist grip produced on intellectual life after World War II operated like a vaccine in the following decades. European geographers detected very early the tendency to submit scientific statements to any kind of external status or allegiance. For example, Popper (1945) has belatedly but profoundly marked European social sciences, even in a diffuse way, because it strongly echoed with scholars' daily life during the postwar period. Popper's criticism of the epistemological prostheses that protect "big" structuralist systems like Marxism and psychoanalysis seems not to have had the same impact on North American social sciences. Firstly because the positivist paradigm was dominant at that time, and secondly because the danger of a possible loss of independence by scientific research was not that strong, therefore hardly perceived. The "science" summit of the triangle is therefore the most critical if we try to compare both corpora.

\subsubsection{H2 Space: divergent layouts of the intellectual stage}

A common point between Europe and North America is that it is possible to claim a geographer's disciplinary identity while paying at the same time little attention to space and spatiality as well as to spatial components of social theory. This is probably a little more visible in North America, where dissociation between two opposed epistemologies and research practices can be observed. On one side, we have a technology-driven, positivist approach, totally or partially encompassed in the GIS world, desperately searching for "general laws of space". On the other side, "literary" 
and post-modern discourses, marked by strong political commitments, show their reluctance to using maps, or any kind of social theory that would give space a significant explanatory power. In the European case, this trend towards a polite but radical separation between positivist spatialism and postmodern anti-spatialism exists as well.

A difference is perceptible, however, as European geographies maintain a more or less strong tie between these two polarities in a picture that also includes other significant theoretical orientations. The ability to bring together in the same hall, for the same academic event, structuralist and actorsoriented, positivist and constructivist, "cultural" and "social" geographers and to have them discuss together is certainly greater in Europe than in North America.

Two reasons can be evoked to explain this difference. First, the persistence of disciplinary affiliations: in contrast to Europe, most North American geographers are not located in a department of geography and there is not always a clear distinction between geography, urban sociology, and urban studies. David Harvey is clearly tagged as a geographer, Susan Fainstein as an urban studies scholar, and Ed Soja as both. They meet their fellow geographers at AAG annual meetings but their everyday partners come from other disciplines. This can be seen as a good point, as we can measure everyday how the still-overwhelming weight of disciplinary institutions hinders innovation logics in many European higher-education systems. However, disciplines "hold" their people and prevent them from being incautious when they cross borderlines of disciplinary territories. Conversely, in North America, weaker disciplinary logics allow scholars to borrow intellectual material from any other field with a lesser risk of internal but also external "epistemological police" intervention.

As a matter of fact, relations between disciplines are much more regulated by the market of ideas in North America and by something that could be called an institutional intellectual scene in Europe. Philosophers, who defend the exclusivity of being "generalist" thinkers, traditionally dominate this scene. In Europe (at least "continental"), doing geography means knowing little outside the official geographical authors and if you try a getaway you will put yourself in danger both by your discipline's intellectual authorities ("It is not geography") and by those of the "territory" you have tried to "invade" ("You are not entitled to do sociology, or anthropology, or philosophy"). The result is an excess of border-crossing assurance in North America, an excess of cautiousness in Europe.

More generally, the figure of the European intellectual is not only significant per se as an indicator of a certain circulation of ideas in a larger cultural environment. One of the somehow paradoxical outcomes of this situation is that it is more difficult in Europe to declare a membership in "such or such" school of thought. Doing so means being involved in a permanent debate with a substantial entry token because you are supposed to be a recognised specialist of the founders' works. It is not only a matter of personal preferences or of career plan. In North America, this threshold of course exists at the highest level, but we can observe a significant number of academic geographers quoting, in an ever-reproduced ritual, Derrida, Foucault, Lefebvre, or Deleuze without having seriously read their works. I do not contend that all European geographers that mention those authors have a complete knowledge of those authors' contributions, but I am reasonably sure that it is a little less rewarding and a little more risky to utilise them as a mere supporter scarf or fraternity tee-shirt.

For instance, Henri Lefebvre readings in the United States are very peculiar because he has been understood as a classical Marxist while in his effective context (1968 France), he has been considered a maverick, speaking Marxian language but undermining Marxism's legitimacy on urban issues. We should not be upset by this: any translation is a re-invention and even in our native language any reception is always a translation, too. What we can imagine is another way of translating Lefebvre, which would be more cautious regarding its context and more interested in detecting in his works some premises of what we are working on today.

\subsubsection{H3 Society: two narratives}

One of the major differences between North American and European societies lies in the relation between civil society and politics. In Europe, the far-right parties are strong and have got stronger during the last years, but in the US, the Republicans, whose rhetoric is at least comparable to the European radical-populist Right ran the federal administration 28 years out of 40 between 1968 and 2008, as in western Europe all governing coalitions have been formed in the centre-right or centre-left zones of the political life. There are of course complex and powerful historical reasons that explain these differences, but one aspect of this divergence is that in Europe, the legitimacy of cultural elites has so far been more protected than in North America. This means that European intellectuals feel much more at home in their own society than North American scholars. Although simplistic, the metaphor of science workers entrenched in their campus to resist a hostile political society makes sense. Academia has been structurally induced to detect conspiracies each time they perceive a discrepancy between their ideas and the mainstream ideologies outside universities. Attitudes such as "follow the money" or "follow the power" are typically North American. In Europe, the risk is comparable but with opposite outcomes: scholars often perceive their social status as that of a deprived and despised aristocracy, rival to the upstart gentry based on money. They then contend to intrinsically represent the people, the voiceless, the "social movement" even if they have not received a clear mandate for this. A part of the success of Pierre Bourdieu's construction about "economic" and "cultural" capital derives from this perception. Both narratives have undesirable epistemic 
effects. The European stance has the inconvenience of generating a certain insensibility to ordinary "social concerns" as the North American one does not create good conditions for free theoretical debates.

\section{Conclusion: theoretical Pluralism as an overriding necessity}

Let's summarise the issue. The existence of a neostructuralist hegemony in North American geography is not a problem per se. In the long term, disputable ideas are criticised and possibly replaced by other ideas. Or a more or less lasting period of cohabitation between contradictory propositions, theories, and paradigms takes place. This is the way social sciences go. A concern emerges when there is the risk that a local theoretical hegemony becomes global and watertight to alternative views. Furthermore, this risk does actually exist because of two particular processes: the global linguistic hegemony of the English language and a "peer-review" system that reinforces pre-existing majorities and consensuses.

The existence of a global vehicular language in social sciences is a major event and clearly a positive one. It is beyond any doubt a powerful tool to turn the project of a universal knowledge into reality. However, during the current, severaldecades-long period, marked by a substantial linguistic-skill gap between native Anglophones and the rest of the scholars, the first group possesses a rent that, consciously or not, can be used in a restrictive sense. If we look at the composition of the most prominent Anglophone journals in geography, we can notice there is a certain ratio of non-native Anglophones in the scientific committees or enlarged editorial boards, but if we look into the effective executive teams, native Anglophones are a clear majority and, therefore, rule. This is easily understandable, without any conspiratorial hypothesis: to run the mill, journals need linguistically efficient people. However, this technical point generates heavy consequences: Anglophone scholars are immersed in an Anglophone scientific milieu, and more generally cultural environments.

Differences between linguistic areas are useful if speakers from each of them strive to outreach the richness of others. Some of these cultural differences can be seen as symmetrical: for instance, the Anglo-Saxon empiricist tradition and the "Continental" metaphysical tradition can both play a positive role as resources for research if they are mobilised with the required level of reflexivity. Now there are also several asymmetries between Anglophone and non-Anglophone geographies: the linguistic domination of English activates the metonymic self-fulfilling prophecy of representing the entire world thanks to one language, while experiencing this domination enhances the awareness of an enduring diversity and multilingual practices. Because of these asymmetries, there is a serious risk of a loss of innovative power inside a research process that would be excessively standardised and epistemologically clumsy. This is all the more true that, due to the emergence of English as a general global language, the native Anglophone speakers have become the worst foreignlanguage-skilled people throughout the world. Hence the paradox that those who bear the responsibility to welcome theoretical pluralism thanks to the English language tend actually, in spite of themselves, to exclude theoretical pluralism because of the English language.

As for peer-review issues, this is not the place to develop something like a "swot analysis" of this evaluation system in academia. Let us just say that the awareness of the risks it encompasses is now substantially documented, not only about the possibility regarding a lack of detection of factual errors, and not only in social sciences. The conservative resultant of this kind of filter is easy to understand: if some of my colleagues propose a breakthrough innovation in my field, I have objective reasons to fear it because (i) they could become institutional rivals and (ii) even more, because they disrupt the equilibrium of my own intellectual construction. Communalism, or its corporatist variant, plays a reinforcing role (positive feedback) here. In this kind of context, if an author does not recognise my allegiance or my alignments, he becomes more than a rival: he becomes a foe. When the old assesses the new, the victory of the new is not granted. In the case of a theoretical hegemony in a particular field, the impact is devastating because checks and balances do not work any more in a monolithic environment. If now an initially local hegemony comes to be generalised at the global scale by a linguistic domination, the worst becomes possible.

Everything brought together, we are in a position to identify significant smoke signals about the risk for innovation in social sciences of space.

At the end of this reflection, three recommendations can be suggested:

1. the necessity of cultural pluralism in social theory. Example: the variety of Lefebvre's receptions;

2. the importance of using all available resources in European geography and to create, namely thanks to English language, a space of interaction between the various schools of thought present in Europe;

3. the relevance of an intense dialogue with North American geography, avoiding the laziness of copycats, which will inevitably be less exciting than the originals.

My purpose is not to protect European geography against outer influences, but to invite all scholars in the globalised geography in which we live to take advantage of all available resources in geography.

By writing this article, I did not have the ambition of carrying out a general "cross-cultural" assessment. I had the more modest purpose to show that we, geographers, whatever the place we are working and living in, should not be intimidated by the mainstream of North American geographical productions and that we should more frequently 
adopt a fearless, if not radical, critical attitude. In doing so, my goal would be by no means to suggest a "secessionist" European geography, but to use the best of our multiand trans-continental research culture to add fresh ideas, methods, and frameworks and, eventually, to enhance the general perspective of a social theory of space. Singularity does not mean particularism here, but a specific contribution to a patiently constructed universality.

Edited by: O. Söderström

Reviewed by: two anonymous referees

\section{References}

Brooks, D.: Bobos in Paradise. The New Upper Class and How They Got There, New York: Simon \& Schuster, 2000.

Fainstein, S.: The Just City, Ithaca: Cornell University Press. 1991: Unthinking Social Science: The Limits of Nineteenth Century Paradigms, Cambridge: Polity, 2010.

Florida, R.: The Rise of the Creative Class. And How It's Transforming Work, Leisure and Everyday Life, New York: Basic Books, 2002.

Florida, R.: Cities and the Creative Class, 2005. Oxford : Routledge, 2005.

Hamnett, C.: The Blind Men and the Elephant: The explanation of gentrification, Transactions of the Institute of British Geographers, 16, 173-189, 1991.

Harvey, D.: Social Justice and the City, London: Edward Arnold, 1973.

Jacobs, J.: The Economy of Cities, New York: Random House, 1969.

Latour, B. and Woolgar, S.: Laboratory Life: The Social Construction of Scientific Facts, London: Sage, 1979.

Lazega, E.: Sociologie néo-structuraliste, in: La théorie sociale contemporaine, edited by: Bronner, G. and Keucheyan, R., Paris: Presses Universitaires de France, 113-130, 2011.

Lees, L., Slater, T., and Wyly, E.: The Gentrification Reader, Oxford: Routledge, 2010.
Ley, D.: Inner city resurgence units societal context, paper presented to the AAG Annual Conference, New Orleans, 1978.

Ley, D.: Alternative explanations for inner city gentrification : A Canadian assessment, Annals of the Association of American Geographers, 76, 521-535, 1986.

Lévy, J.: L'espace légitime, Paris: Presses de Siences Po, 1994.

Lévy, J.: [Notice] "Justice spatiale”, in Lévy \& Lussault, 2013.

Lévy, J. and Lussault, M.: Dictionnaire de la géographie et de l'espace des sociétés, Paris: Belin, new edition, 2013.

Lofland, L. H.: A World of Strangers: Order and Action in Urban Public Space, New York: Basic Books, 1973.

Lofland, Lyn H.: The Public Realm, New York: Aldine de Gruyter, 1998.

Malanga, S.: The Curse of the Creative Class, City Journal, Winter 2004: 36-45, 2004.

Mitchell, D.: The Right to the City: Social Justice and the Fight for Public Space, New York: The Guilford Press, 2003.

Peck, J.: Struggling with the Creative Class, International Journal of Urban and Regional Research, 29, 740-770, 2005.

Popper, K. R.: The Open Society and Its Enemies, London: Routledge, 2 vol, 1945.

Rawls, J.: A Theory of Justice, Cambridge: Harvard University Press, 1971.

Sassen, S.: The Global City: New York, London, Tokyo, Princeton: Princeton University Press, 1991.

Slater, T.: "The Eviction of Critical Perspectives from Gentrification Research", International Journal of Urban and Regional Research Volume 30.4 December 2006, 737-757, 2006.

Smith, N. and Williams, P.: Gentrification of the City, London: George, Allen and Unwin, 1986.

Smith, N.: The New Urban Frontier: Gentrification and the Revanchist City, London: Routledge, 1996.

Soja, E.: Seeking Spatial Justice, Minneapolis: Minnesota University Press, 2010.

Wallerstein, I.: Unthinking Social Science: The Limits of Nineteenth Century Paradigms, Cambridge: Polity, 1991.

Wimmer, A. and Glick Schiller, N.: Methodological Nationalism and Beyond: Nation-state Building, Migration and the Social Sciences, Global Networks, 2, 301-334, 2002. 